\title{
Evaluasi Kesesuaian dan Daya Dukung Lahan untuk Pengembangan Pariwisata di Wilayah Kepesisiran Pulau Breuh
}

\author{
Hidayatullah, Nurul Khakhim, Andri Kurniawan
}

Masuk: 18122020 / Diterima: 21012021 / Dipublikasi: 30062021

\begin{abstract}
The development of tourism, especially in coastal areas and small islands, will significantly influence natural environmental conditions. It is because coastal areas are known to be very dynamic and prone to pollution and degradation. Therefore, to avoid degradation and dysfunction of land in the coastal areas of Breuh Island as a result of tourism development, it is necessary to conduct a study to develop sustainable marine tourism. This study includes the land suitability evaluation with the potential resources and carrying capacity available. This study aims to evaluate the suitability and carrying capacity of the land for tourism development in the coastal area of Breuh Island, Pulo Aceh District. This study was carried out in three research locations, namely Lambaro Beach, Balu Beach, and Rinon Beach. The method used in this research is the survey method and determination of sample points by purposive sampling. The analytical method used in this study is the tourism suitability index (TSI) and the land carrying capacity (LCC). The results showed that the coastal areas of Breuh Island, especially Lambaro, Balu, and Rinon beaches, are very suitable (S1) to be developed as a coastal tourism area for beach recreational activities. The carrying capacity of the area for recreational tourism activities on Lambaro Beach is 4469 people/day. Balu Beach has an LCC of 4250 people/day, while the LCC for Rinon Beach is 3,335 people/day.
\end{abstract}

Keywords: Land Suitability Evaluation; Carrying Capacity; Coastal; Tourism Development

\begin{abstract}
Abstrak Pengembangan pariwisata terutama di wilayah kepesisiran dan pulau kecil akan membawa pengaruh besar terhadap kondisi lingkungan alami di sana karena kawasan pesisir dikenal dikenal sangat dinamis serta rawan terhadap pencemaran dan kerusakan lingkungan. Oleh karena itu, untuk menghindari terjadinya degradasi dan disfungsi lahan di kawasan pesisir Pulau Breuh akibat dari pengembangan wisata, maka perlu dilakukan suatu kajian untuk pengembangan wisata bahari yang berkelanjutan. Kajian ini meliputi evaluasi kesesuaian pemanfaatan lahan dengan potensi sumberdaya dan daya dukung yang tersedia. Penelitian ini bertujuan untuk mengevaluasi kesesuaian serta daya dukung lahan untuk pengembangan pariwisata di wilayah kepesisiran Pulau Breuh, Kecamatan Pulo Aceh. Pengambilan data dalam penelitian ini dilakukan di tiga lokasi penelitian yaitu Pantai Lambaro, Pantai Balu dan Pantai Rinon. Metode yang digunakan dalam penelitian ini adalah metode survei dan penentuan titik sampel secara purposive sampling. Sedangkan untuk metode analisisnya menggunakan analisis indeks kesesuaian wisata (IKW) dan daya dukung kawasan (DKK). Hasil penelitian menunjukkan bahwa wilayah kepesisiran Pulau Breuh khususnya Pantai Lambaro, Balu dan Rinon sangat sesuai (S1) dikembangkan sebagai kawasan wisata pesisir untuk aktivitas rekreasi pantai. Untuk daya dukung kawasan untuk kegiatan wisata rekreasi di Pantai Lambaro adalah 4469 orang/hari. Pantai Balu memiliki DDK 4250 orang/hari sedangkan DDK untuk Pantai Rinon yaitu 3.335 orang/hari.
\end{abstract}

Kata kunci: Evaluasi Kesesuaian Lahan; Daya Dukung Lahan; Wilayah Pesisir; Pengembangan Pariwisata

This is an open access article under the CC BY-SA license.

Copyright $\odot 2021$ by Author. Published by Universitas Pendidikan Ganesha.

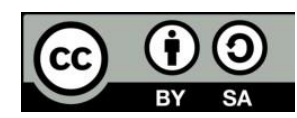




\section{Pendahuluan}

Indonesia merupakan negara kepulauan yang terdiri dari 16,065 pulau dengan luas wilayah 1,916,862 $\mathrm{km}^{2}$ (tidak termasuk ZEE) serta memiliki panjang garis pantai $99.093 \mathrm{~km}$ (Badan Informasi Geospasial, 2018). Hal ini berakibat pada tersedianya potensi sumberdaya yang ada di kawasan pesisir dan pulau-pulau kecil. Kawasan pesisir dan pulau-pulau kecil Indonesia memiliki potensi sumber daya alam yang begitu besar (Dahuri, 2001). Sumber daya tersebut meliputi sumber daya yang dapat diperbaharui (renewable resources) seperti ikan, lamun (seagrass), rumput laut (seaweed), terumbu karang (coral reef), dan mangrove, maupun sumber daya yang tidak dapat diperbaharui (non-renewable resources) termasuk di dalamnya minyak bumi dan gas, bahan tambang/galian seperti timah, biji pasir serta bahan tambang lainnya. Selain memiliki potensi fisik yang begitu besar, kawasan pesisir dan pulau-pulau kecil juga mempunyai jasa-jasa lingkungan (enviromental resources) potensial untuk dikembangkan seperti pariwisata, khususnya wisata bahari (Dahuri, 2001).

Pengembangan wisata bahari sebagai tujuan wisata (destinasi) menjadi salah satu strategi yang bisa dilakukan pemerintah maupun swasta untuk mempromosikan wilayah tersebut sebagai daerah tujuan wisata guna meningkatkan perekonomian dan kesempatan kerja (Yulisa, Johan, \& Hartono, 2016). Dampak positif yang dapat diterima, tidak hanya pada peningkatan pertumbuhan ekonomi dan perluasan kesempatan kerja, tetapi juga akan mendorong masyarakat untuk

Hidayatullah, Nurul Khakhim, Andri Kurniawan

Universitas Gadjah Mada, Indonesia

hidayatullahmail@gmail.com menjaga dan memelihara keindahan alam yang ditawarkan sebagai objek wisata (Baiquni, 2004). Pengembangan obyek wisata yang ditata dengan baik akan turut berperan dalam meminimalisir kerusakan lingkungan, terutama wilayah pantai dan pesisir yang merupakan wilayah yang rentan terhadap kerusakan lingkungan (Bahar \& Tambaru, 2010).

Pulau Breuh merupakan salah satu pulau kecil berpenghuni yang berada di gugusan Pulo Aceh yang sedang dikembangkan sebagai destinasi wisata bahari. Pulau ini hanya memiliki luas daratan $63 \mathrm{~km} 2$ yang terletak di ujung barat Pulau Sumatera dan berbatasan langsung dengan Samudera Hindia. Secara administrasi Pulau Breuh terletak di Kecamatan Pulo Aceh, Kabupaten Aceh Besar. Pulau ini memiliki topografi wilayah yang berbukit dengan daya tarik berupa pantai berpasir putih yang landai, terumbu karang serta landscape yang indah dan masih alami (Badan Pusat Statistik Kabupaten Aceh Besar, 2017).

Pengembangan pariwisata terutama di wilayah kepesisiran dan pulau kecil jika tidak dikelola dengan baik akan membawa dampak negatif terhadap lingkungan alami disana (Kurniawan, Adrianto, Bengen, \& Prasetyo, 2019). Dampak negatif tersebut meliputi pencemaran lingkungan (Wilhelmsson, Thompson, Holmström, Lindén, \& Eriksson-Hägg, 2013), kerusakan pada terumbu karang (Kurniawan et al., 2019) kerusakan padang lamun (Cullen-Unsworth, Leanne C.Unsworth, 2014) dan lain-lain.

Masalah utama dalam pengembangan pulau kecil adalah terbatasnya ketersediaan air minum (Tatas, Budipriyanto, Khoiri, Lestari, \& Rahman, 2015) rendahnya kondisi sosial ekonomi penduduk, aksesibilitas yang sulit (Anwar, 2010), ancaman bencana 
alam tinggi, rendahnya daya dukung lingkungan (Kerstetter \& Bricker, 2012) keterbatasan infrastruktur dan kelembagaan, serta rentan terhadap pencemaran.

Oleh karena itu, untuk menghindari terjadinya degradasi dan disfungsi lahan di kawasan pesisir Pulau Breuh akibat dari pengembangan wisata, maka perlu dilakukan suatu kajian meliputi evaluasi kesesuaian dan daya dukung lahan untuk kegiatan wisata pesisir. Evaluasi kesesuaian lahan bertujuan untuk mengetahui sekaligus mengukur potensi yang dimiliki suatu lahan yang diperuntukkan untuk bagi penggunaan lahan tertentu dalam kasus ini untuk pariwisata, sedangkan analisis daya dukung kawasan bertujuan untuk mengetahui jumlah maksimum pengunjung yang dapat ditampung suatu objek wisata tanpa mengganggu keutuhan ekosistem alaminya.

$$
\text { Kajian mengenai evaluasi }
$$
kesesuaian dan daya dukung lahan untuk pengembangan wisata pesisir sebelumnya belum pernah dilakukan di tempat ini, sehingga diharapkan dengan adanya kajian ini dapat memberikan masukan serta arahan bagi pengembangan wisata pesisir di Pulau Breuh yang lebih baik. Penelitian ini bertujuan untuk mengevaluasi kesesuaian lahan untuk kegiatan wisata rekreasi pantai di kawasan pesisir Pulau Breuh, dan menganalisis daya dukung (carrying capacity) kawasan pesisir Pulau Breuh untuk kegiatan wisata rekreasi pantai.

\section{Metode}

\section{Waktu dan lokasi penelitian}

Penelitian ini dilaksanakan pada bulan Januari 2020. Lokasi penelitian terbagi atas tiga lokasi yaitu Pantai Lambaro Pantai Balu dan Pantai Rinon. Secara administrasi ketiga lokasi penelitian ini berada di Pulau Breuh Kecamatan Pulo Aceh Kabupaten Aceh Besar, Provinsi Aceh.

\section{Alat dan bahan penelitian}

Alat dan bahan yang digunakan dalam penelitian ini yaitu Global Poseitioning System (GPS), Roll meter, Secchi Disk, Buku alat tulis dan Current meter.

\section{Teknik pengumpulan data}

Penelitian ini menggunakan data primer yaitu data diperoleh dengan melakukan pengamatan dan pengukuran langsung di lapangan seperti data kedalaman perairan, material penyusun pantai, lebar pantai, material dasar perairan, kecepatan arus, tinggi gelombang, kemiringan pantai, kecerahan perairan, penutup lahan, pantai biota berbahaya, dan ketersediaan air bersih (tawar).

Pengumpulan data kesesuaian dan daya dukung lahan untuk kegiatan wisata rekreasi pantai dalam penelitian ini dilakukan dengan pengamatan dan pengukuran langsung di lapangan (survei) terhadap parameter-parameter penelitian yang sudah ditetapkan. Adapun parameter yang digunakan mengukur kesesuaian wisata rekreasi pantai meliputi kedalaman perairan, material penyusun pantai, lebar pantai, material dasar perairan, kecepatan arus, tinggi gelombang, kemiringan pantai, kecerahan perairan, penutup lahan, pantai biota berbahaya, dan ketersediaan air bersih (tawar) (Yulianda, 2007).

\section{Teknik Analisis data}

Analisis yang gunakan untuk mengevaluasi kesesuaian lahan yaitu matriks dan rumus kesesuaian lahan untuk wisata rekreasi pantai (Yulianda, 2007) Adapun matrik kesesuaian lahan

21 | Media Komunikasi Geografi, Vol. 22, No. 1, Juni 2021: 19-30 
untuk wisata rekreasi pantai dapat dilihat pada Tabel 1, sedangkan untuk rumusnyanya adalah sebagai berikut:

$\mathrm{IKW}=\Sigma\left[\frac{N i}{N m a k s}\right] \mathrm{Ni} \times 100 \%$

Keterangan :

$\mathrm{IKW} \quad=$ Indeks kesesuaian wisata (\%)

$\mathrm{Ni}=$ Nilai parameter ke-i (bobot $\mathrm{x}$ skore)
$\mathrm{N}$ maks = Nilai maksimum (84)

Adapun kelas kesesuaiannya dibagi menjadi 4 kelas kesesuaian yaitu:

S1 = Sangat sesuai, dengan nilai 75$100 \%$

S2 = Cukup sesuai, dengan nilai 60$<75 \%$

S3 = Sesuai bersyarat, dengan nilai35$<60 \%$

$\mathrm{N}=$ Tidak Sesuai, dengan nilai $<35 \%$

Tabel 1. Matriks evaluasi kesesuaian lahan untuk wisata pantai

\begin{tabular}{|c|c|c|c|c|c|c|c|c|c|c|}
\hline No & Parameter & Bobot & $\begin{array}{c}\text { Kategori } \\
\text { S1 }\end{array}$ & Skor & $\begin{array}{l}\text { Kategori } \\
\text { S2 }\end{array}$ & Skor & $\begin{array}{c}\text { Kategori } \\
\text { S3 }\end{array}$ & Skor & Kategori N & Skor \\
\hline 1 & $\begin{array}{l}\text { Kedalaman } \\
\text { Perairan }(\mathrm{m})\end{array}$ & 5 & $0-3$ & 3 & $>3-6$ & 2 & $>6-10$ & 1 & $>10$ & 0 \\
\hline 2 & $\begin{array}{l}\text { Material } \\
\text { penyusun } \\
\text { Pantai }\end{array}$ & 5 & $\begin{array}{l}\text { Pasir } \\
\text { Putih }\end{array}$ & 3 & $\begin{array}{l}\text { Pasir } \\
\text { Putih, } \\
\text { Sedikit } \\
\text { Karang }\end{array}$ & 2 & $\begin{array}{c}\text { Pasir } \\
\text { Hitam, } \\
\text { Berkaran } \\
\text { g, Sedikit } \\
\text { Terjal }\end{array}$ & 1 & $\begin{array}{l}\text { Lumpur } \\
\text { Berbatu, } \\
\text { Terjal }\end{array}$ & 0 \\
\hline 3 & $\begin{array}{l}\text { Lebar Pantai } \\
\text { (m) }\end{array}$ & 5 & $>15$ & 3 & $10-15$ & 2 & $3-<10$ & 1 & $<3$ & 0 \\
\hline 4 & $\begin{array}{l}\text { Material Dasar } \\
\text { Perairan }\end{array}$ & 3 & Pasir & 3 & $\begin{array}{l}\text { Karang } \\
\text { Berpasir }\end{array}$ & 2 & $\begin{array}{c}\text { Pasir } \\
\text { Berlumpu } \\
r\end{array}$ & 1 & Lumpur & 0 \\
\hline 5 & $\begin{array}{l}\text { Kecepatan } \\
\text { Arus }(\mathrm{m} / \mathrm{dt})\end{array}$ & 3 & $0-0,17$ & 3 & $\begin{array}{c}>0,17- \\
0,34\end{array}$ & 2 & $\begin{array}{c}>0,34- \\
0,51\end{array}$ & 1 & $>0,51$ & 0 \\
\hline 6 & $\begin{array}{l}\text { Kemiringan } \\
\text { Pantai }\left({ }^{0}\right)\end{array}$ & 3 & $<10$ & 3 & $10-25$ & 2 & $25-45$ & 1 & $>45$ & 0 \\
\hline 7 & $\begin{array}{l}\text { Kecerahan } \\
\text { Perairan }(\mathrm{m})\end{array}$ & 1 & $>10$ & 3 & $>5-10$ & 2 & $3-5$ & 1 & $<3$ & 0 \\
\hline 8 & $\begin{array}{l}\text { Penutup Lahan } \\
\text { pantai }\end{array}$ & 1 & $\begin{array}{l}\text { Kelapa, } \\
\text { Lahan } \\
\text { Terbuka }\end{array}$ & 3 & $\begin{array}{l}\text { Semak } \\
\text { Belukar } \\
\text { Rendah, } \\
\text { Savana }\end{array}$ & 2 & $\begin{array}{l}\text { Belukar } \\
\text { Tinggi }\end{array}$ & 1 & $\begin{array}{c}\text { Hutan } \\
\text { Bakau, } \\
\text { Pemukiman } \\
\text {, Pelabuhan } \\
\end{array}$ & 0 \\
\hline 9 & $\begin{array}{l}\text { Biota } \\
\text { Berbahaya }\end{array}$ & 1 & Tidak Ada & 3 & Bulu Babi & 2 & $\begin{array}{l}\text { Bulu Babi, } \\
\text { ikan Pari }\end{array}$ & 1 & $\begin{array}{l}\text { Bulu Babi, } \\
\text { Ikan Pari, } \\
\text { Lepu, Hiu }\end{array}$ & 0 \\
\hline 10 & $\begin{array}{l}\text { Ketersediaan } \\
\text { Air bersih } \\
\text { (Tawar) } \\
(\text { Jarak/km) }\end{array}$ & 1 & $<0,5$ & 3 & $>0,5-1$ & 2 & $>1-2$ & 1 & $>2$ & 0 \\
\hline
\end{tabular}

Sumber: Modifikasi Yulianda. (2007)

Metode analisis yang digunakan dalam menghitung daya dukung lahan untuk pengembangan pariwisata di wilayah kepesisiran yaitu dengan menggunakan konsep daya dukung kawasan (DDK). DDK adalah jumlah maksimum pengunjung yang secara fisik dapat ditampung di kawasan yang disediakan pada waktu tertentu tanpa menimbulkan gangguan pada alam dan manusia. Perhitungan DKK dilakukan dengan menggunakan pendekatan
Yulianda., dkk. (2010) dalam bentuk rumus seperti berikut:

Dimana :

$$
\mathrm{DDK}=\mathrm{K} \times \frac{L p}{L t} \times \frac{W t}{W p}
$$

$$
\begin{aligned}
& \text { DDK = Daya } \\
& \text { kawasan(orang/hari) } \\
& \text { dukung } \\
& \mathrm{K} \text { = Potensi ekologis pengunjung } \\
& \text { per satuan unit area } \\
& L p=\text { Luas area atau panjang area } \\
& \text { yang dapat di manfaatkan } \\
& \text { Lt = Unit area untuk kategori tertentu }
\end{aligned}
$$



Wt = Waktu disediakan oleh kawasan untuk kegiatan wisata
$\mathrm{Wp}=$ Waktu yang dihabiskan oleh pengunjung untuk setiap kegiatan.

Penentuan wt dan wp dalam penelitian ini dilakukan dengan mewawancarai langsung pengunjung dan pengelola objek wisata seperti pada Tabel 2.

Tabel 2 Ekologis Pengunjung (K), unit area (Lt), dan waktu rata-rata wt, wp

\begin{tabular}{|c|c|c|c|c|}
\hline Jenis Kegiatan & $\begin{array}{c}\text { K (Keterangan } \\
\text { Pengunjung) }\end{array}$ & Unit Area (Lt) & $\begin{array}{c}\text { Waktu yang dihabis } \\
\text { pengunjung untuk } \\
\text { setiap kegiatan (wp) }\end{array}$ & $\begin{array}{c}\text { Total waktu } \\
\mathbf{1} \text { hari } \\
\text { (wt) }\end{array}$ \\
\hline Rekreasi Pantai & 1 & $50 \mathrm{~m}^{2}$ & 3 jam & 10 jam \\
\hline
\end{tabular}

Sumber : Modifikasi Yulianda. (2007)

\section{Hasil dan Pembahasan}

\section{Evaluasi kesesuaian lahan untuk wisata rekreasi pantai.}

Evaluasi kesesuaian lahan bertujuan untuk mengetahui tingkat kesesuaian suatu lahan yang telah dikembangkan terhadap penggunaan tertentu. Evaluasi kesesuaian lahan dalam penelitian ini lebih berfokus untuk mengetahui tingkat kesesuaian suatu objek wisata pesisir berdasarkan karakteristik fisik wilayah untuk aktivitas rekreasi pantai. Hal ini juga bertujuan agar dalam pengembangan suatu obyek wisata sesuai dengan kondisi fisik dan karakteristik wilayahnya, sehingga dapat memaksimalkan potensi yang ada serta meminimalkan ancaman dari kerusakan ekosistem alami di wilayah tersebut.

Adapun parameter yang digunakan untuk mengukur kesesuaian lahan wisata kategori rekreasi pantai menurut Yulianda. (2007) yang terdiri dari 10 parameter yaitu, parameter kedalaman perairan, tipe pantai, lebar pantai, material dasar,kecepatan arus, kecerahan perairan, kemiringan pantai, penutupan lahan pantai, biota berbahaya, dan ketersediaan air tawar. Hasil pengukuran parameter kesesuaian lahan wisata kategori rekreasi dapat dilihat pada Tabel 3.

Kedalaman perairan merupakan salah satu parameter yang sangat penting dalam menentukan kesesuaian suatu wilayah untuk dijadikan kawasan wisata rekreasi pantai karena berkaitan dengan keselamatan wisatawan khususnya saat berenang. Semakin dangkalnya suatu perairan maka semakin sesuai kawasan itu dijadikan lokasi wisata rekreasi pantai. Dari hasil pengukuran di Pantai Lambaro, Balu dan Rinon kedalaman perairan di pantai ini berkisar 2- 2,8 meter dengan jarak 15 meter dari bibir pantai dan dikategorikan sesuai (S1) untuk wisata rekreasi pantai menurut Yulianda (2007). Selain kedalaman perairan, kecepatan arus, material dasar perairan dan biota berbahaya juga menjadi bahan pertimbangan dalam pengembangan wisata rekreasi pantai karena berkaitan juga dengan faktor keamanan wisatawan.

Informasi kecepatan arus sangat penting untuk diketahui, hal tersebut sangat berhubungan dengan keamanan wisatawan terutama wisatawan yang melakukan aktivitas renang. Hal serupa juga diungkapkan (Nybakken, 1992) bahwa kecepatan arus laut memiliki erat kaitannya dengan keamanan dan kenyaman wisata terutama untuk aktivitas berenang. Pantai yang memiliki kecepatan arus yang lemah jauh lebih aman dan sangat sesuai untuk kegiatan renang dibandingkan pantai yang memiliki kecepatan arus yang kuat 
sehingga berpotensi menimbulkan bahaya karena dapat menyeret wisatawan yang sedang berenang. Hasil pengukuran, kecepatan arus di Pantai Lambaro berkisar $24 \mathrm{~cm} /$ detik yang dikategorikan sesuai (S2). Pantai Balu memiliki kecepatan arus $22 \mathrm{~cm} /$ detik dan dikategorikan sesuai (S2). Sedangkan Pantai Rinon memiliki kecepatan arus berkisar $28 \mathrm{~cm} /$ detik yang dikategorikan sesuai (S2). Walaupun secara umum kecepatan arus ketiga pantai ini dikategorikan sangat sesuai - sesuai untuk wisata rekreasi pantai termasuk untuk aktivitas renang, namun saat musim barat kecepatan arus ketiga pantai ini dapat meningkat sampai $>50 \mathrm{~cm} /$ detik sehingga berbahaya bagi wisatawan terutama yang melakukan aktivitas renang.

Tabel 3. Hasil Indeks kesesuaian wisata untuk kategori rekreasi pantai

\begin{tabular}{|c|c|c|c|c|c|c|c|c|c|c|c|}
\hline \multirow{2}{*}{ No } & \multirow{2}{*}{ Parameter } & \multirow{2}{*}{ Bobot } & \multicolumn{3}{|c|}{ Pantai Lambaro } & \multicolumn{3}{|c|}{ Pantai Balu } & \multicolumn{3}{|c|}{ Pantai Rinon } \\
\hline & & & Hasil & Skor & Jumlah & Hasil & Skor & Jumlah & Hasil & Skor & Jumlah \\
\hline 1 & $\begin{array}{l}\text { Kedalaman } \\
\text { Perairan }(\mathrm{m})\end{array}$ & 5 & 2,41 & 3 & 15 & 1,98 & 3 & 15 & 2,82 & 3 & 15 \\
\hline 2 & $\begin{array}{l}\text { Material } \\
\text { penyusun } \\
\text { Pantai }\end{array}$ & 5 & Pasir putih & 3 & 15 & Pasir putih & 3 & 15 & $\begin{array}{c}\text { Pasir Putih, } \\
\text { Sedikit } \\
\text { Karang }\end{array}$ & 2 & 10 \\
\hline 3 & $\begin{array}{l}\text { Lebar Pantai } \\
\text { (m) }\end{array}$ & 5 & $17-38$ & 3 & 15 & $25-49$ & 3 & 15 & $18-28$ & 3 & 15 \\
\hline 4 & $\begin{array}{l}\text { Material } \\
\text { Dasar } \\
\text { Perairan }\end{array}$ & 3 & $\begin{array}{c}\text { Berpasir, } \\
\text { sedikit } \\
\text { berkarang }\end{array}$ & 2 & 6 & Berpasir & 3 & 9 & $\begin{array}{c}\text { Berpasir, } \\
\text { sedikit } \\
\text { berkarang }\end{array}$ & 2 & 6 \\
\hline 5 & $\begin{array}{l}\text { Kecepatan } \\
\text { Arus }(\mathrm{m} / \mathrm{dt})\end{array}$ & 3 & 0,24 & 2 & 6 & 22 & 2 & 6 & $>28$ & 2 & 6 \\
\hline 6 & $\begin{array}{l}\text { Kemiringan } \\
\text { Pantai }\left({ }^{\circ}\right)\end{array}$ & 3 & 4 & 3 & 9 & 2 & 3 & 9 & 6 & 3 & 9 \\
\hline 7 & $\begin{array}{l}\text { Kecerahan } \\
\text { Perairan }(\mathrm{m})\end{array}$ & 1 & 5,8 & 2 & 2 & 7 & 2 & 2 & 6,2 & 2 & 2 \\
\hline 8 & $\begin{array}{l}\text { Penutup } \\
\text { Lahan pantai }\end{array}$ & 1 & $\begin{array}{l}\text { Lahan } \\
\text { Terbuka }\end{array}$ & 3 & 3 & $\begin{array}{c}\text { Lahan } \\
\text { Terbuka, } \\
\text { semak } \\
\text { belukar }\end{array}$ & 2 & 2 & $\begin{array}{c}\text { Lahan } \\
\text { terbuka, } \\
\text { Semak } \\
\text { Belukar }\end{array}$ & 2 & 2 \\
\hline 9 & $\begin{array}{l}\text { Biota } \\
\text { Berbahaya }\end{array}$ & 1 & Tidak Ada & 3 & 3 & Tidak Ada & 3 & 3 & Tidak Ada & 3 & 3 \\
\hline 10 & $\begin{array}{l}\text { Ketersediaan } \\
\text { Air bersih } \\
\text { (Tawar) } \\
\text { (Jarak/km) }\end{array}$ & 1 & 0,37 & 3 & 3 & $>2$ & 0 & 0 & 0,22 & 3 & 3 \\
\hline & Total $\Sigma(\mathrm{Ni})$ & & & & 77 & & & 76 & & & 71 \\
\hline & IKW (\%) & & \multicolumn{3}{|c|}{$91,66 \%$} & \multicolumn{3}{|c|}{$90,47 \%$} & \multicolumn{3}{|c|}{$84,52 \%$} \\
\hline & Kategori & & \multicolumn{3}{|c|}{ S1 } & \multicolumn{3}{|c|}{ S1 } & \multicolumn{3}{|c|}{ S1 } \\
\hline
\end{tabular}

Sumber : Hasil Analisis, 2020.

Material dasar perairan dijadikan parameter karena berkaitan dengan keamanan dan kenyamanan wisatawan. Pantai yang memiliki material dasar yang halus seperti pasir sebagai tempat berpijak saat berenang atau hanya sekedar main air akan memberikan rasa kenyaman dan keamanan bagi wisatawan dibandingkan pantai yang material dasarnya batu atau karang yang dapat menyebabkan kaki mereka terluka.
Berdasarkan hasil pengamatan visual di lapangan, material penyusun Pantai Lambaro dan pantai Balu didominasi pasir putih dengan ukuran sedang-halus. Sedangkan Pantai Rinon material penyusunnya pasir putih dan sedikit berkarang. Pantai Lambaro dan Balu dikategorikan sangat sesuai (S1) untuk wisata rekreasi pantai jika dilihat dari material penyusunya sedangkan Pantai Rinon dikategorikan sesuai (S2) karena 
material penyusunya pasir sedikit bercampur karang. Kondisi ini sesuai dengan Yulianda (2007) bahwa pantai dengan material dasarnya pasir sangat sesuai untuk kegiatan wisata pantai dibandingkan dengan pantai yang berbatu atau berkarang karena dapat mengganggu kenyamanan wisatawan.

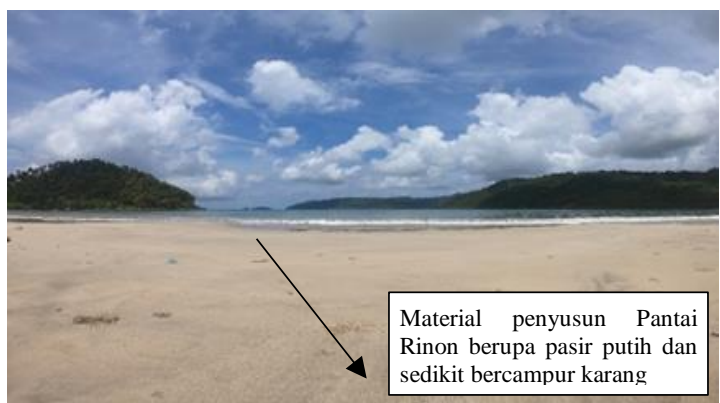

Gambar 1. Material penyusun Pantai Rinon berupa pasir putih dan sedikit bercampur karang (sumber: foto lapangan 2020)

Faktor lain yang menjadi dapat mengancam keamanan dari wisatawan saat melakukan melakukan wisata rekreasi pantai terutama aktivitas renang yaitu adanya biota berbahaya di kawasan wisata. Hal ini sesuai dengan (Akbar, 2013) bahwa wisatawan harus waspada terhadap kegiatan wisata, jika di kawasan tersebut terdapat biota berbahaya. Biota berbahaya tersebut seperti bulu babi, ikan pari, ubur-ubur dan dan yang paling berbahaya ikan hiu. Semakin sedikit biota berbaya yang ditemukan di kawasan wisata maka akan semakin baik. Untuk mengetahui ada tidaknya biota berbahaya di kawasan wisata pantai, dilakukan dengan dua cara yaitu dengan melakukan pengamatan langsung (snorkeling) dan wawancara dengan para pengunjung, masyarakat sekitar dan pihak pengelola. Berdasarkan hasil pengamatan dan wawancara diketahui bahwa tidak ditemukannya biota berbahaya untuk jarak 20 meter dari bibir pantai baik itu di kawasan pantai Lambaro, Balu maupun
Pantai Rinon sehingga ketiga pantai ini aman dan sangat sesuai (S1) untuk kegiatan wisata rekreasi pantai.

Selain faktor keamanan, faktor kenyamanan juga jadi bahan pertimbangan dalam pengembangan objek wisata rekreasi pantai seperti material penyusun pantai, lebar pantai, kemiringan pantai kecerahan perairan dan penutup lahan. Menurut Yulianda (2007) pantai dengan material penyusun pasir sangat baik untuk dikembangkan untuk wisata rekreasi pantai dibandingkan dengan pantai yang berbatu, berkarang atau pantai yang didominasi lumpur karena dapat mengganggu kenyamanan wisatawan. Hal ini juga diperkuat oleh (Wabang, Yulianda, \& Susanto, 2018) yang menyatakan bahwa Pantai yang material penyusunnya didominasi pasir lebih diminati wisatawan dari pada pantai berbatu dan berlumpur jika dimanfaatkan untuk rekreasi pantai. Penentuan material penyusun pantai dapat dilakukan dengan mengamati langsung di lapangan secara visual.

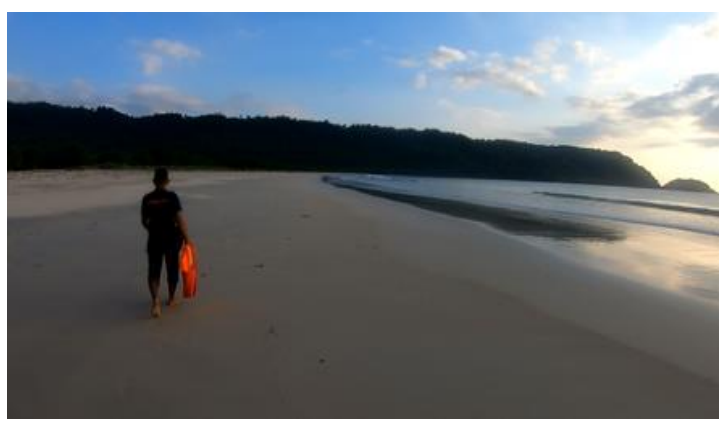

Gambar 2. Kondisi Pantai Balu yang memiliki pantai yang lebar dan pasir yang halus (sumber: foto lapangan 2020)

Berdasarkan hasil pengamatan visual di lapangan, material penyusun Pantai Lambaro dan Balu didominasi pasir putih dengan ukuran sedang-halus, sedangkan Pantai Rinon material penyusunnya pasir putih dan sedikit berkarang. Pantai Lambaro dan Balu dikategorikan sangat sesuai (S1) untuk 
wisata rekreasi pantai jika dilihat dari material penyusunya sedangkan Pantai Rinon dikategorikan sesuai (S2). Selain memiliki pasir yang putih, ketiga pantai ini juga memiliki kemiringan yang datarlandai yang berkisar 2-6\% dan dikategorikan sangat sesuai (S1) untuk wisata rekreasi pantai. Hal ini sesuai dengan pendapat Sunarto (1991) dalam Chasanah, dkk (2017) bahwa kemiringan lereng yang datar sampai landai sangat sesuai untuk kegiatan wisata.

Lebar pantai juga berpengaruh terhadap luas area pantai dan kenyamanan wisatawan. Area pantai yang luas akan menambah kenyamanan wisatawan dibandingkan pantai yang memiliki luas areanya sempit. Semakin luasnya area pantai, maka akan semakin leluasa wisatawan dalam melakukan aktivitasnya. Menurut Yulianda (2007) pantai yang memiliki lebar lebih dari 15 meter sangat sesuai untuk wisata rekreasi pantai, sedangkan pantai yang lebarnya kurang dari 3 meter dianggap tidak sesuai untuk wisata rekreasi pantai. Berdasarkan hasil pengukuran di lapangan dengan menggunakan roll meter diketahui bahwa lebar pantai Lambaro berkisar 20-38 meter dan dikategorikan sangat sesuai (S1). Begitu juga dengan Pantai Balu dan Pantai Rinon yang dikategorikan sangat sesuai (S1) karena memiliki lebar pantai diatas 15 meter.

Kecerahan perairan menjadi daya tarik tersendiri bagi wisatawan karena berkaitan dengan keindahan pemandangan dari perairan. Menurut Yulianda (2007) Semakin cerah suatu perairan maka semakin sesuai untuk dijadikan lokasi wisata baik itu untuk aktivitas rekreasi pantai, snorkeling maupun diving.

Berdasarkan pengamatan dan pengukuran langsung diperoleh bahwa kecerahan perairan di Pantai Lambaro yaitu 5,8 $\mathrm{m}$ dan kecerahan pantai di Pantai $7 \mathrm{~m}$ sedangkan kecerahan perairan di Pantai Rinon adalah 6,2 m. Ketiga pantai ini memiliki kecerahan perairan yang di kategorikan sesuai (S2) untuk wisata pantai. Namun nilai kecerahan perairan disekitaran Pulau Breuh, termasuk ketiga pantai ini dapat berubah menjadi lebih keruh saat musim barat terjadi. Hal ini sesuai dengan pendapat Effendi dalam Wabang dkk (2018) yang menjelaskan bahwa nilai kecerahan sangat dipengaruhi oleh padatan tersuspensi dan kekeruhan, keadaan cuaca, waktu pengukuran, serta ketelitian orang yang melakukan pengukuran.

Penutupan lahan dalam matriks kesesuaian wisata kategori rekreasi dibagi menjadi lahan terbuka dan kelapa, semak belukar rendah dan semak belukar tinggi, pemukiman dan pelabuhan. Adapun penutupan lahan di Pantai Lambaro yaitu lahan terbuka dengan vegetasi pohon cemara laut (casuarina equistifolia) dan pandan pantai (pandanus odorifer). Sedangkan Pantai Balu memiliki penutup lahan terbuka yang luas serta terdapat semak belukar rendah. begitu juga Pantai Rinon selain memiliki penutup lahan terbuka juga terdapat semak belukar.

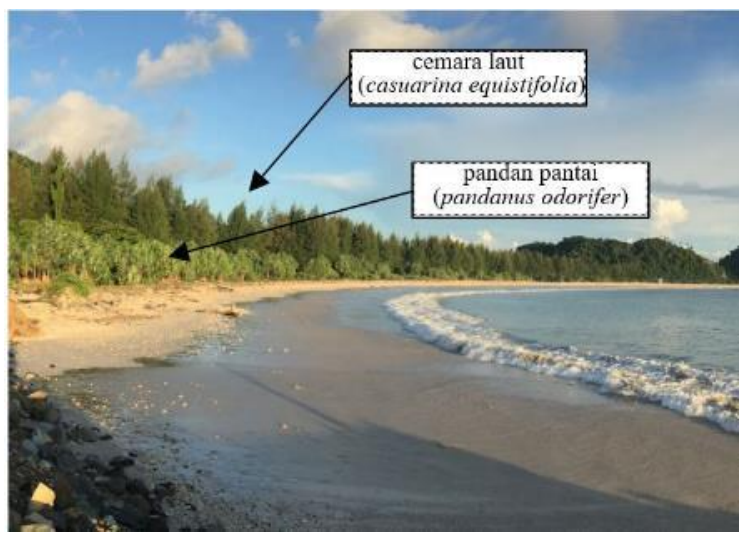

Gambar 3. Vegetasi Pantai Lambaro (sumber: foto lapangan 2020) 
Ketersediaan sumber air tawar mutlak diperlukan untuk menunjang pengembangan potensi kepariwisataan di wilayah pulau-pulau kecil (Dahuri 2003 dalam Wabang 2018). Khusus di lokasi wisata, ketersediaan sumber air tawar dibutuhkan untuk mendukung fasilitas pengelolaan maupun pelayanan wisata sehingga menjadi kriteria penting terhadap penilaian kelayakan prioritas pengembangan wisata pantai. Hasil pengukuran, jarak ketersediaan air tawar di Pantai Lambaro dan Pantai Rinon berjarak kurang dari 500 meter. Hal ini dikarenakan lokasi kedua pantai ini yang dekat dengan pemukiman yang tersedia air tawar atau air bersih. Berbeda dengan Pantai Balu lokasinya jauh dari pemukiman. Adapun jarak ketersediaan air tawar di Pantai Balu lebih dari $2 \mathrm{~km}$ atau dikategorikan tidak sesuai $(\mathrm{N})$.

Berdasarkan hasil pengukuran dan perhitungan dari 10 parameter kesesuaian lahan untuk kegiatan wisata rekreasi pantai (tabel 3), diketahui bahwa Pantai Lambaro, Pantai Balu dan Pantai Rinon termasuk dalam kategori kawasan yang sangat sesuai (S1) untuk kegiatan wisata rekreasi pantai. Adapun masing-masing pantai memperoleh nilai IKW 91,66\% untuk Pantai Lambaro, 90,47 \% untuk Pantai Balu dan 84,52 \% untuk Pantai Rinon. Hal sejalan dengan hasil penelitian Silvitiani, dkk, (2018) bahwa suatu kawasan dapat dikatakan sangat sesuai (S1) apabila nilai IKW kawasan tersebut mencapai antara 75$100 \%$. Kondisi ini menunjukkan bahwa ketiga pantai tersebut jika ditinjau dari karakteristik fisik wilayah sangat sesuai untuk dikembangkan sebagai objek wisata rekreasi pantai.

\section{Analisa Daya Dukung Kawasan (DDK) untuk wisata rekreasi pantai}

Wilayah kepesisiran merupakan kawasan yang sangat rentan terhadap perubahan lingkungan. Perubahan lingkungan di wilayah kepesisiran dapat diakibatkan faktor alam maupun aktivitas manusia yang memanfaatkan wilayah tersebut. Salah satu pemanfaatan wilayah kepesisiran yang sering dilakukan yaitu sebagai kawasan wisata. Pemanfaatan wilayah kepesisiran sebagai kawasan wisata yang melebihi daya dukungnya akan membawa pada kerusakan lingkungan di kawasan tersebut. Oleh karena itu kajian mengenai daya dukung suatu ekosistem berdasarkan potensi sumberdaya alam pesisir dan laut sangatlah diperlukan untuk mendapatkan informasi yang tepat dan akurat yang dapat digunakan sebagai dasar pedoman dalam mengelola wilayah pesisir dan juga laut (Dahuri, 2003 dalam Wabang, 2018).

Analisis daya dukung kawasan wisata yang dimaksud dalam penelitian ini yaitu daya dukung yang menunjukkan jumlah maksimum pengunjung ditinjau secara fisik yang dapat ditampung dalam suatu kawasan wisata pada waktu tertentu tanpa menimbulkan kerusakan pada kawasan lingkungannya (Yulianda, 2007).

Tabel 4. Daya dukung kawasan rekreasi pantai

\begin{tabular}{|l|l|c|c|c|c|c|c|c|}
\hline No & Nama Lokasi & $\begin{array}{c}\text { Panjang Garis } \\
\text { Pantai (Gisik) }\end{array}$ & $\mathbf{K}$ & $\mathbf{L p}\left(\mathbf{m}^{\mathbf{2}}\right)$ & $\mathbf{L t}\left(\mathbf{m}^{\mathbf{2}}\right)$ & $\mathbf{W t}(\mathbf{j a m})$ & $\mathbf{W} \mathbf{p}(\mathbf{j a m})$ & $\begin{array}{c}\text { DKK } \\
\text { Orang/hari }\end{array}$ \\
\hline 1 & Pantai Lambaro & $1.121 \mathrm{~m}$ & 1 & 67.102 & 50 & 10 & 3 & 4469 \\
\hline 2 & Pantai Balu & $1.283 \mathrm{~m}$ & 1 & 63.816 & 50 & 10 & 3 & 4250 \\
\hline 3 & Pantai Rinon & $1,162 \mathrm{~m}$ & 1 & 50.076 & 50 & 10 & 3 & 3.335 \\
\hline
\end{tabular}

Sumber: Hasil analisis, 2020 
Pada Tabel 4. Diketahui Pantai Lambaro memiliki luas area yang dapat digunakan untuk kegiatan wisata rekreasi pantai seluas $67.102 \mathrm{~m} 2$ (Lp) dan untuk Pantai Balu seluas $63.816 \mathrm{~m}^{2}$ sedangkan Pantai Rinon luas area yang dapat digunakan untuk kegiatan wisata rekreasi pantai lebih sempit dibandingkan kedua pantai sebelumnya yaitu 50,076 m2. Waktu yang disediakan untuk kegiatan wisata diketiga pantai ini sama yaitu 10 jam (Wt) mulai dari jam 09.00-16.00 WIB dan waktu rata-rata yang dihabiskan pengunjung untuk kegiatan rekreasi pantai yaitu 3 jam $(\mathrm{Wp})$. Hasil perhitungan daya dukung kawasan (DDK) wisata untuk aktivitas rekreasi adalah sebanyak 4.469 orang/hari untuk Pantai Lambaro, 4.250 orang/hari untuk Pantai Balu dan 3.335 orang/hari untuk Pantai Rinon (tabel 4.). Nilai DDK ini dapat dijadikan sebagai pedoman bagi pengelola untuk mengetahui kemampuan maksimal lingkungan alami kawasan wisata dalam menerima dan menampung wisatawan perharinya sehingga kerusakan lingkungan dapat diminimalisir.

Adapun jumlah wisatawan yang mengunjungi ketiga obyek wisata rekreasi pantai ini terus meningkat, terutama sejak dikenalkan sebagai wisata bahari pada 2018 oleh Pemerintah Kabupaten Aceh Besar. Namun sayang jumlah pastinya belum diketahui karena belum terdata dengan baik. Meskipun demikian, menurut LEPA (Lembaga Ekowisata Pulo Aceh) untuk jumlah wisatawan yang mengunjungi objek wisata rekreasi pantai, baik itu Pantai Lambaro, Pantai Balu maupun Pantai Rinon dapat dipastikan masih jauh dari ambang batas maksimum pengunjung yang diperbolehkan, karena jumlah wisatawan masih sangat sedikit, hanya berkisar puluhan dan masih didominasi masyarakat sekitar. Adapun untuk fasilitas penunjang wisata diketiga tempat tersebut, saat ini masih sangat minim, sehingga diharapkan perlu untuk ada penambahan fasilitas serta pengelolaan yang lebih baik kedepan.

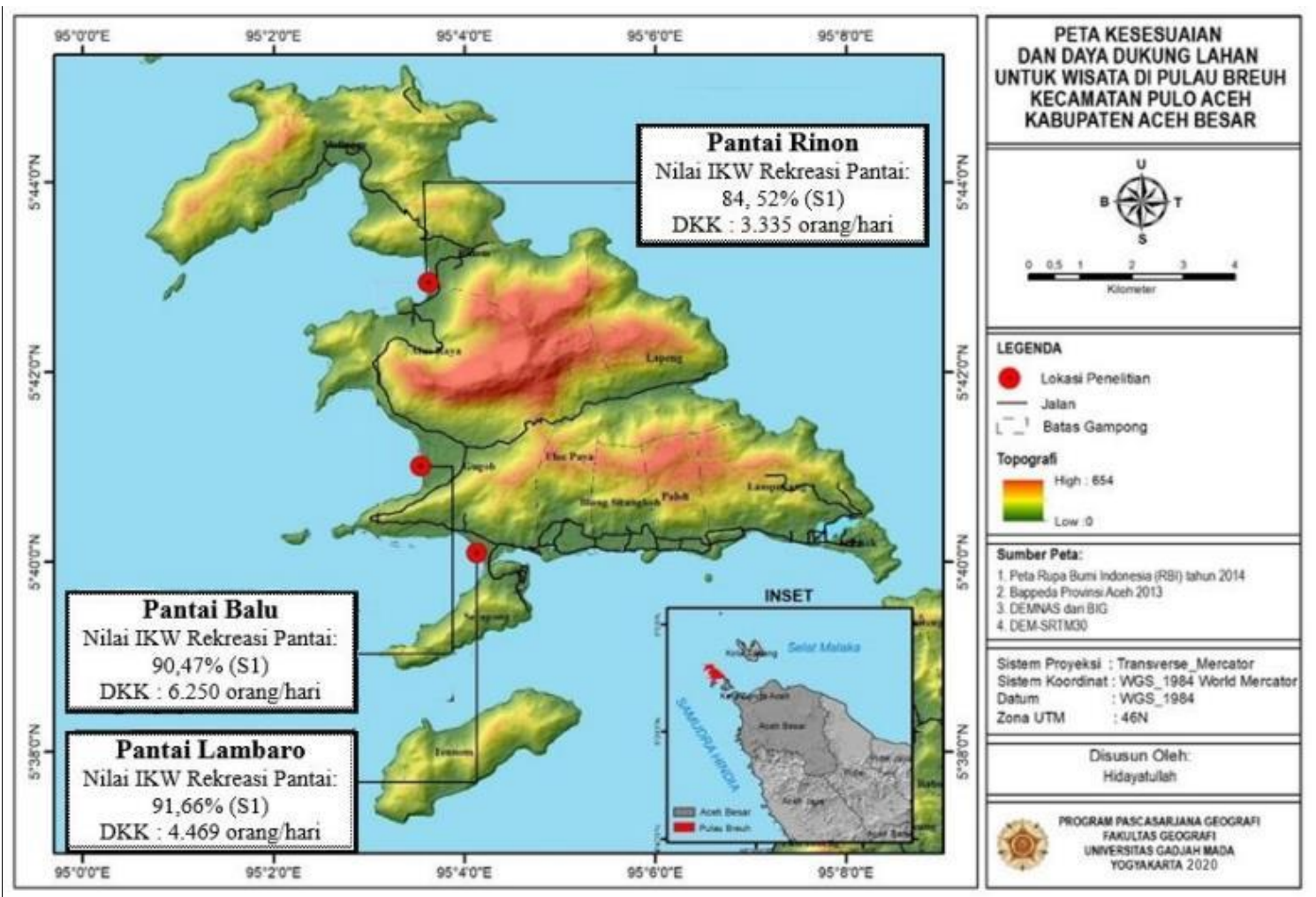

Gambar 4. Peta kesesuaian dan daya dukung lahan untuk kegiatan wisata pantai.

28 | Media Komunikasi Geografi, Vol. 22, No. 1, Juni 2021: 19-30 


\section{Penutup}

Kesesuaian lahan untuk kegiatan wisata pesisir kategori rekreasi pantai di Pulau Breuh diwakilkan oleh tiga lokasi pantai yaitu Pantai Lambaro, Balu dan Rinon. Pantai Lambaro memiliki nilai IKW $91,66 \%$ dan dikategorikan sangat sesuai (S1). Begitu juga dengan Pantai Balu memiliki nilai IKW 90,47\%, dan Pantai Rinon $84,52 \%$ yang di kategorikan sangat sesuai (S1). Hal ini menunjukkan bahwa ketiga pantai ini berdasarkan karakteristik fisik sangat sesuai dikembangkan sebagai kawasan wisata rekreasi pantai. Analisis daya dukung (carring capacity) kawasan wisata bertujuan untuk mengetahui jumlah maksimum wisatawan yang dapat ditampung oleh suatu obyek wisata tanpa menyebabkan kerusakan lingkungan di tempat tersebut.Adapun daya dukung kawasan (DDK) untuk aktivitas wisata rekreasi pantai di pesisir Pulau Breuh khususnya di Pantai Lambaro adalah 4469 orang/hari. Pantai Balu memiliki DDK 4250 orang/hari sedangkan DDK untuk Pantai Rinon yaitu 3.335 orang/hari. Untuk saat ini, ketiga pantai tersebut belum melampaui daya dukung kawasan, karena jumlah wisatawan yang yang melakukan aktivitas wisata rekreasi pantai di wilayah ini masih sangat sedikit dan masih di dominasi penduduk lokal.

\section{Daftar Pustaka}

Akbar. (2013). Environmental Marketing pada Ekowisata Pesisir. Institut Pertanian Bogor.

Anwar, R. (2010). Pengembangan Dan Keberlanjutan Wisata Bahari di Wilayah Pesisir dan Pulau-Pulau Kecil Kota Makassa. Institusi Pertanian Bogor.

Badan Informasi Geospasial. (2018). pentingnya informasi geospasial untuk menata laut-indonesia. Retrieved October 10, 2018, from http://big.go.id/berita-surta/show/ pentingnya-informasi-geospasialuntuk-menata-laut-indonesia

Badan Pusat Statistik Kabupaten Aceh Besar. (2017). Pulo Aceh Dalam Angka 2017. Retrieved October 3, 2018,from

https://acehbesarkab.bps.go.id/

Bahar, A., \& Tambaru, R. (2010). Wisata Bahari Di Kabupaten Polewali Mandar. Jurnal Wisata Bahari Polman- UNRI.

Baiquni, M. (2004). Pariwisata Bahari Sebagai Alternatif Ekonomi Masyarakat Pesisir dan Pengembangan Wilayah. Jurnal Pariwisata STIEPAR, 5, 119-246.

Chasanah, I., Purnomo, P. W., \& Haeruddin, H. (2017). Analisis Kesesuaian Wisata Pantai Jodo Desa Sidorejo Kecamatan Gringsing Kabupaten Batang. Jurnal Pengelolaan Sumberdaya Alam Dan Lingkungan (Journal of Natural Resources and Environmental Management). https://doi.org/10.29244/jpsl.7.3.235 $-243$

Cullen-Unsworth, Leanne C.Unsworth, R. K. F. (2014). Biodiversity, ecosystem services, and the conservation of seagrass meadows. In Coastal Conservation. https://doi.org/10.1017/cbo9781139 137089.005

Dahuri, R. (2001). Pengelolaan Ruang Wilayah Pesisir Dan Lautan Seiring Dengan Pelaksanaan Otonomi Daerah. Jurnal Sosial Dan Pembangunan.

Kerstetter, D. L., \& Bricker, K. S. (2012). Relationship between carrying capacity of small Island tourism destinations and quality-of-life. In Handbook of Tourism and Qualityof-Life Research: Enhancing the Lives of Tourists and Residents of Host Communities. https://doi.org/10.1007/978-94-0072288-0

Kurniawan, F., Adrianto, L., Bengen, D. G., \& Prasetyo, L. B. (2019). The social-ecological status of small islands: An evaluation of island 
tourism destination management in Indonesia. Tourism Management Perspectives.

https://doi.org/10.1016/j.tmp.2019.0 4.004

Nybakken. (1992). Biologi Laut Suatu Pendekatan Ekologis. PT. Gramedia Pustaka Utama.

Silvitiani, K., Yulianda, F., \& Siregar, V. P. (2018). Perencanaan Pengembangan Wisata Pantai Berbasis Potensi Sumberdaya Alam Dan Daya Dukung Kawasan Di Desa Sawarna, Banten (Coastal Tourism Development Based on Natural Resources and Carrying Capacity in Sawarna Village, Banten). Jurnal Manusia Dan Lingkungan.

https://doi.org/10.22146/jml.23076

Tatas, Budipriyanto, A., Khoiri, M., Lestari, W., \& Rahman, A. (2015). Study on water balance in Poteran A small island in East Java, Indonesia. In Procedia Engineering. https://doi.org/10.1016/j.proeng.201 5.11 .034

Wabang, I. L., Yulianda, F., \& Susanto, H. A. (2018). Kajian karakteristik tipologi pantai untuk pengembangan wisata rekreasi pantai di suka alam perairan selat pantar kabupaten alor. Albacore Jurnal Penelitian Perikanan Laut. https://doi.org/10.29244/core.1.2.19 9-209

Wilhelmsson, D., Thompson, R. C., Holmström, K., Lindén, O., \& Eriksson-Hägg, H. (2013). Marine Pollution. In Managing Ocean Environments in a Changing Climate: Sustainability and Economic Perspectives. https://doi.org/10.1016/B978-0-12407668-6.00006-9

Yulianda, F. (2007). Ekowisata Bahari Sebagai Alternatif Pemanfaatan Sumber Daya Pesisir Berbasis Konservasi. Bogor.
Yulisa, E. N., Johan, Y., \& Hartono, D. (2016). Analisis kesesuaian dan daya dukung ekowisata pantai kategori rekreasi pantai laguna desa merpas kabupaten kaur. Jurnal enggano.

https://doi.org/10.31186/jenggano.1. 1.97-111 